\title{
Monte Carlo simulation of district heating system short-term operation in electricity markets
}

\author{
Ilias Dimoulkas, \\ Mikael Amelin \\ Royal Institute of Technology, \\ Brinellvägen 8 , \\ 11428 Stockholm, Sweden \\ E-mail iliasd@kth.se
}

\begin{abstract}
Energy generation in district heating $(\mathrm{DH})$ systems is usually done in combined heat and power (CHP) units which can efficiently produce both useful heat and electric power. There can also exist heat only boilers, electric heaters, heat pumps and heat storage tanks. The coupling of heat and power generation in the CHP units and the possibility to store heat for later use makes the short-term operation scheduling of such systems quite challenging. Furthermore, big DH systems produce power that is sold in the electricity markets. This makes the operation scheduling problem even more complex as the uncertainty of the electricity prices in the markets should be considered. To make optimal decisions under uncertainty, various mathematical optimization tools were developed, such as stochastic programming and robust optimization. In this paper, an approach based on a Monte Carlo simulation is followed. Initially, a model of DH system short-term operation and power trading is mathematically formulated. Then, this model is used to run a Monte Carlo simulation for a case study system where the values of stochastic parameters are simulated using autoregressive models. Results demonstrate that simulation is fast, taking 300-400 runs to converge. A comparison of two system configurations shows that the use of heat storage increases the daily expected profit by $11 \%$. Finally, the electricity price volatility in this case study is such that mainly two CHP units are operating for most of the time.
\end{abstract}

Keywords: district heating, combined heat and power, short-term operation, Monte Carlo simulation, electricity markets

\section{INTRODUCTION}

District heating (DH) systems can generate both useful heat and power with high efficiency in the combined heat and power (CHP) units. Furthermore, they have the capability to store heat in heat storage accumulators or even consume power to produce heat by means of electric boilers and heat pumps. According to [1], by the year 2050, district heating should cover $50 \%$ of the total heat demand in contrast to $10 \%$ which covers today.

Short-term operation scheduling of a district heating system involves decisions regarding units to be operated and cover the heat and power demand during the following period which may range from the following hours to the following few days. The coupling of power 
and heat production in the CHP units increases the complexity of this scheduling problem. The first studies in the literature considered only CHP units using non-linear deterministic models [2]. In such models the system was considered to have both fixed power and heat loads.

The introduction of competitive electricity markets increased the complexity of the problem and altered the objectives. While previously the CHP operators were trying to minimize the operational costs and cover the power and heat loads under a fixed price scheme, now the target includes among others the profit maximization in the electricity markets [3]. Furthermore, new modelling techniques that help derive optimal decisions under uncertainty have found application in the operation scheduling of power systems in general, and in district heating systems in particular. For example, stochastic programming is used in [4-5] while robust optimization in [6].

Monte Carlo simulation [7] is an efficient method to solve problems with stochastic parameters using a deterministic model. Its general approach is based on random sampling of the stochastic parameters. For each sample, the deterministic problem is solved and if enough samples have been used, the solution to the original probabilistic problem is given by the expected value of all solutions. Monte Carlo methods have been previously used in power system unit commitment problems [8], production cost calculation [9] and security assessment [10].

In this paper, the Monte Carlo method is used to derive the optimal day-ahead operation scheduling of a DH system which also includes the power traded in the electricity markets. Three types of electricity markets are considered: day-ahead (spot) market, intraday market, and balancing (real-time) market. Electricity market prices and volumes are the stochastic parameters of the problem. As the time series of these parameters present autocorrelation and interdependence, various autoregressive models (SARIMA, ARMAX, AR) are used to simulate them $[5,13]$.

The rest of this paper is organized as follows: Section 2 provides the methodology. It starts with a short description of the DH systems and the electricity markets in order to make easier the understanding of the mathematical formulation which follows right after. The section closes with the description of the sample creation procedure. Section 3 is the case study. The short-term operation of a realistic DH system is simulated with the Monte Carlo method and the results are presented. Finally, section 4 concludes the paper.

\section{METHODOLOGY}

\section{District heating system overview}

A DH system consists of CHP units, heat boilers, electric boilers, heat pumps and heat accumulators (Fig. 1). CHP units are characterized by the type of turbine they use to produce power. These are: a) back-pressure steam turbines, b) extraction condensing steam turbines, and c) gas turbines. The back-pressure steam turbines operate with a fixed power-to-heat ratio. In some installations, there is the possibility for the steam to bypass the turbine and operate as heat only boiler. The relation between power and heat generation for these two modes can be seen on the right side of Fig. 2 . The gas turbines also operate with a fixed powerto-heat ratio and can be operated as only power generation units. The extraction condensing steam turbines are characterized for their higher flexibility and can be operated in any point of the feasible operation zone described by the grey coloured area in Fig. 2, the left side. Heat boilers produce only heat and they are usually used as back-up systems of the CHP units. The electric boilers or immersion heaters and the heat pumps are consuming power to produce heat. The difference is that heat pumps need a heat source, such as a lake, and they

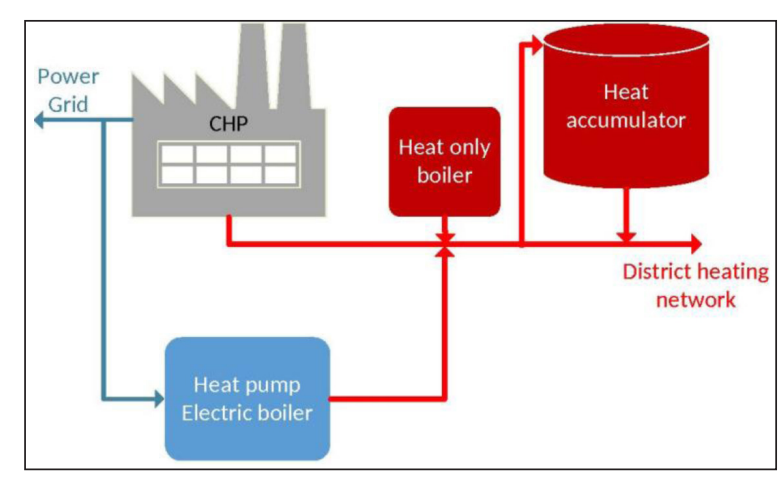

Fig. 1. Main units operating in a district heating system 


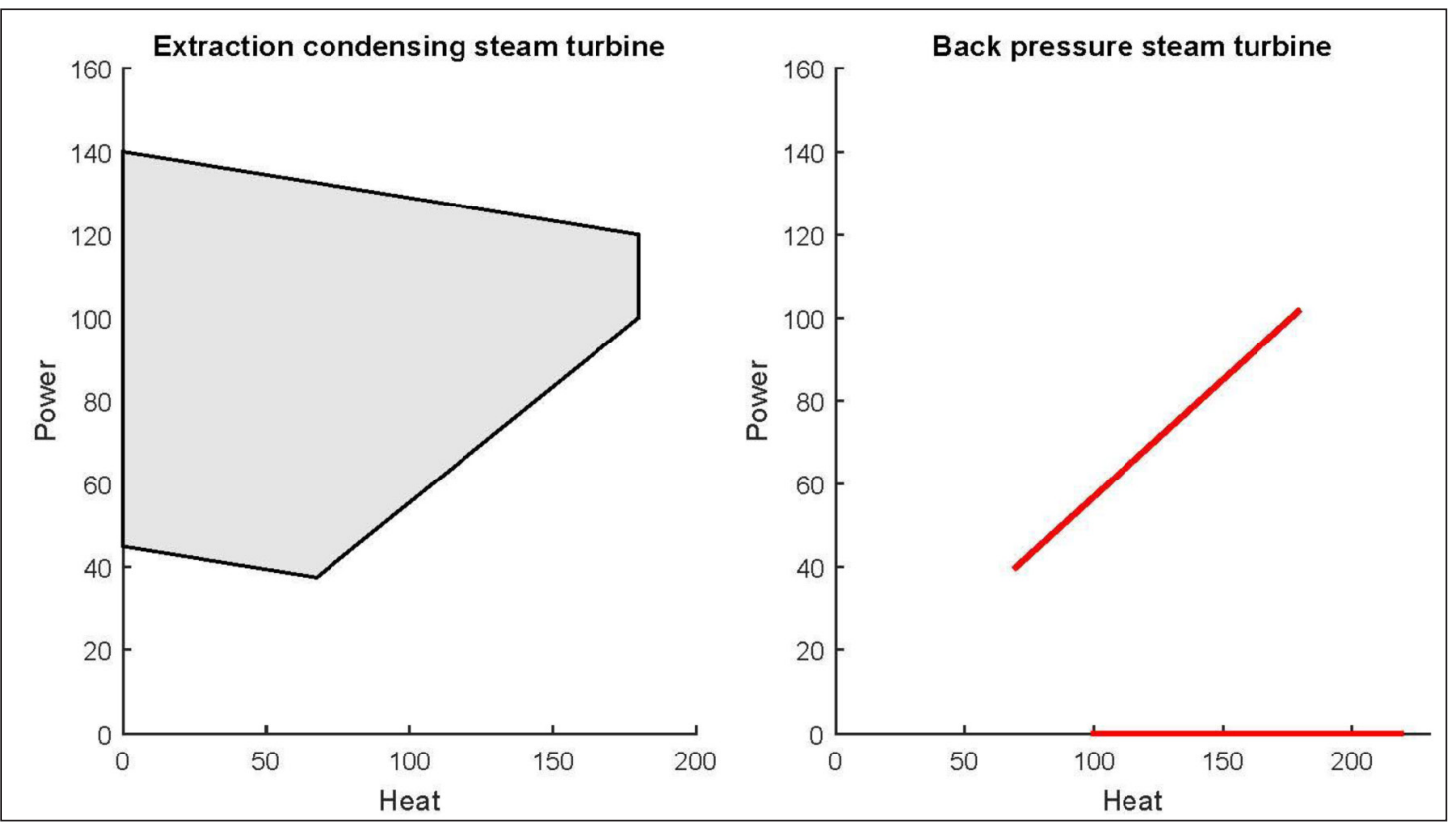

Fig. 2. Power-heat charts of extraction condensing (left) and back-pressure (right) steam turbines

are much more efficient compared to the electric boilers. Finally, the heat accumulators can store hot water for many hours and with very few losses. This provides a possibility for a $\mathrm{DH}$ operator to decouple the heat generation from heat demand.

\section{Electricity markets overview}

There are three main trading floors in modern electricity markets. These are the day-ahead, the intraday, and the balancing electricity markets. Responsible for the first two is the market operator (Nord Pool in Nordic and Baltic region [11]) while for the balancing market responsible is the transmission system operator (TSO, ISO).

The day-ahead, or spot, market is the main trading floor where the majority of power is sold and bought. Power producers and consumers decide on their offering/bidding curves and submit them to the day-ahead market usually until noon the day before the actual power delivery. Then the prices are calculated according to the bids and they are announced to the market players along with power volumes. The long-time interval between market closure and power delivery allows enough time for conventional power plants to start up their units if needed.

The intraday market operates in a similar way to the day-ahead market but trading takes place closer to the power delivery time. This allows pro- ducers with non-dispatchable generation (wind power, solar power, etc.) to make better estimation of their actual generation and take actions that reduce the risk of participating in the day-ahead market.

The balancing market acts as a mechanism where TSOs can obtain balancing power offered by dispatchable power producers in order to keep the power system balanced. This is the so called tertiary control. Pricing in the balancing market provides some incentive for power producers to participate. When they have to up-regulate increasing their power output, they will be paid at a price higher to the price in the day-ahead market. On the other hand, if they have to down-regulate, they will buy back the power which was previously sold to the day-ahead market at a lower price.

\section{Mathematical formulation}

The mathematical formulation of the problem consists of an objective function (1) and several constraints (2-39) which are grouped in different categories for easier reference. More analytically:

\section{Objective function}

The objective function of the problem (1) stands for the profit maximization of a DH system operator. This profit consists of the income of power sold in day-ahead, intraday, and balancing markets, 
minus the cost of power bought from these markets and the cost of operating the units. This last cost includes the variable fuel consumption cost and the costs of starting-up and shutting down the units. An artificial heat shedding cost is added to the objective function to avoid such condition but also to keep the solution feasible.

$$
\begin{aligned}
& \sum_{t=1}^{N_{T}}\left(\lambda_{t}^{\text {spot }} \cdot\left(P_{t}^{s p+}-P_{t}^{s p-}\right)+\lambda_{t}^{i m} \cdot\left(P_{t}^{i m+}-P_{t}^{i m-}\right)\right. \\
& \left.+\lambda_{t}^{b m+} \cdot P_{t}^{b m+}-\lambda_{t}^{b m-} \cdot P_{t}^{b m-}\right) \\
& -\sum_{t=1}^{N_{T}} \sum_{g=1}^{N_{G}}\left(\lambda_{g}^{\text {fuel }} P_{g, t}^{\text {fuel }}+c_{g, t}^{\text {start }} \cdot Y_{g, t}\right. \\
& \left.+c_{g}^{\text {stop }} \cdot Z_{g, t}\right)-\sum_{t=1}^{N_{T}} c^{\text {shed }} \cdot Q_{t}^{\text {shed }}
\end{aligned}
$$

Unit operational limits and fuel functions

The feasible operation zone of an extraction condensing steam turbine (Fig. 2, left side) is defined by constraints $(2-5)$. The fuel consumption function is given by (6).

$$
\begin{aligned}
& \beta_{g}^{e l} \cdot P_{g, t}+\beta_{g}^{\text {th }} \cdot Q_{g, t} \leq \beta_{g}^{e l} \cdot p_{g}^{\max } \cdot U_{g, t} \forall g, t \\
& \beta_{g}^{e l} \cdot P_{g, t}+\beta_{g}^{\text {th }} \cdot Q_{g, t} \geq \beta_{g}^{e l} \cdot p_{g}^{\text {min }} \cdot U_{g, t} \forall g, t \\
& P_{g, t} \geq \alpha_{g} \cdot Q_{g, t} \forall g, t \\
& Q_{g, t} \leq q_{g}^{\max } \forall g, t \\
& P_{g, t}^{\text {fuel }}=\frac{1}{\eta_{g}} \cdot\left(\beta_{g}^{e l} \cdot P_{g, t}+\beta_{g}^{\text {th }} \cdot Q_{g, t}\right) \forall g, t
\end{aligned}
$$

There are two operational modes for a backpressure steam turbine, either producing both heat and power or producing only heat. In the first case it operates with a fixed power-to-heat ratio (7) inside its technical limits (8). In the second case only the heat generation limits are applied (9). Total heat generation is equal to the sum of heat generation in each mode (10) but the unit can operate in only one mode each period (11). The fuel consumption function is given by (13).

$$
\begin{aligned}
& P_{g, t}=\alpha_{g} \cdot Q_{g, t}^{m 1} \forall g, t \\
& p_{g}^{\text {min }} \cdot M_{g, t}^{1} \leq P_{g, t} \leq p_{g}^{\max } \cdot M_{g, t}^{1} \quad \forall g, t
\end{aligned}
$$

$$
\begin{aligned}
& q_{g}^{m i n} \cdot M_{g, t}^{2} \leq Q_{g, t}^{m 2} \leq q_{g}^{\max } \cdot M_{g, t}^{2} \quad \forall g, t \\
& Q_{g, t}=Q_{g, t}^{m 1}+Q_{g, t}^{m 2} \quad \forall g, t \\
& M_{g, t}^{1}+M_{g, t}^{2} \leq 1 \quad \forall g, t \\
& U_{g, t}=M_{g, t}^{1}+M_{g, t}^{2} \quad \forall g, t \\
& P_{g, t}^{\text {fuel }}=\frac{1}{\eta_{g}} \cdot\left(P_{g, t}+Q_{g, t}\right) \forall g, t
\end{aligned}
$$

The operation of a gas turbine is similar to that of a back-pressure steam turbine in CHP mode. It operates with a fixed power-to-heat ratio (14). Here the inequality allows for only power generation while heat is wasted. Power generation limits are given by (15) while fuel consumption by (16).

$$
\begin{aligned}
& P_{g, t} \geq \alpha_{g} \cdot Q_{g, t} \forall g, t \\
& P_{g}^{\text {min }} \cdot U_{g, t} \leq P_{g, t} \leq P_{g}^{\text {max }} \cdot U_{g, t} \quad \forall g, t \\
& P_{g, t}^{\text {fuel }}=\frac{1}{\eta_{g}} \cdot \frac{\alpha_{g}+1}{\alpha_{g}} \cdot P_{g, t} \quad \forall g, t
\end{aligned}
$$

The operation of a heat boiler is described by the heat generation limits (17) and the fuel consumption function (18).

$$
\begin{aligned}
& q_{g}^{\text {min }} \cdot U_{g, t} \leq Q_{g, t} \leq q_{g}^{\max } \cdot U_{g, t} \forall g, t \\
& P_{g, t}^{\text {fuel }}=\frac{Q_{g, t}}{\eta_{g}} \forall g, t
\end{aligned}
$$

The capacity of an electric boiler is given by (19) while the heat generation is a function of the power consumption (20).

$$
\begin{aligned}
& Q_{g, t} \leq q_{g}^{\max } \cdot U_{g, t} \quad \forall g, t \\
& Q_{g, t}=\eta_{g} \cdot P_{g, t}^{c o n} \quad \forall g, t
\end{aligned}
$$

Similarly, heat pump output is limited below and above (21) while the heat generation is the coefficient of performance times the power consumption (22).

$$
\begin{aligned}
& q_{g}^{\min } \cdot U_{g, t} \leq Q_{g, t} \leq q_{g}^{\max } \cdot U_{g, t} \forall g, t \\
& Q_{g, t}=\operatorname{cop}_{g} \cdot P_{g, t}^{\text {con }} \forall g, t
\end{aligned}
$$


The operation of a heat accumulator is defined by its upper and lower heat content limits (23) and the limits of heat flow towards and out of it (24).

$$
\begin{aligned}
& v^{\text {min }} \leq V_{t} \leq v^{\text {max }} \quad \forall t \\
& -q^{\text {flow }} \leq V_{t}-V_{t-1} \leq q^{\text {flow }} \quad \forall t
\end{aligned}
$$

Unit commitment constraints (25-26) define the operating status of all units: operating, starting-up, and shutting down.

$$
\begin{aligned}
& Y_{g, t} \geq U_{g, t}-U_{g, t-1} \quad \forall g, t \\
& Z_{g, t} \geq U_{g, t-1}-U_{g, t} \quad \forall g, t
\end{aligned}
$$

Minimum on (27) and off time (28) constraints indicate the requirement of the units to stay on or off for some time after they have been shut down or turned on, respectively.

$$
\begin{aligned}
& U_{g, t}-U_{g, t-1} \leq U_{g, \tau} \forall \mathrm{g}, t, \tau=t, \ldots, \min \left\{t+l_{g}-1, N_{T}\right\} \\
& U_{g, t-1}-U_{g, t} \leq 1-U_{g, \tau} \forall \mathrm{g}, t, \tau=t, \ldots, \min \left\{t+f_{g}-1, N_{T}\right\}
\end{aligned}
$$

Heat and power output of units can change inside some limits from period to period. These restrictions are defined by the heat (29-30) and power (31-32) ramp constraints.

$$
\begin{aligned}
& Q_{g, t}-Q_{g, t-1} \leq r_{g}^{q \uparrow} \forall g, t \\
& Q_{g, t-1}-Q_{g, t} \leq r_{g}^{q \downarrow} \forall g, t \\
& P_{g, t}-P_{g, t-1} \leq r_{g}^{q \uparrow} \forall g, t \\
& P_{g, t-1}-Q_{g, t} \leq r_{g}^{q \downarrow} \forall g, t
\end{aligned}
$$

\section{Energy balance constraints}

Heat balance constraint (33) defines the balance of heat in the heat storage accumulator: each period the heat content of the storage is equal to the heat content of the previous period reduced due to the losses plus the total heat generation and any heat shedding minus the heat demand. Similarly, power balance constraint (34) defines the power balance between power generation and consumption and the power which is traded in the electricity markets.

$$
\begin{aligned}
& V_{t}=(1-f) \cdot V_{t-1}+\sum_{g=1}^{N_{G}} Q_{g, t} \\
& -q_{t}^{\text {load }}+Q_{t}^{\text {shed }} \quad \forall t \\
& \sum_{g=1}^{N_{G}} P_{g, t}-\sum_{g=1}^{N_{G}} P_{g, t}^{\text {con }}=P_{t}^{s p+}+P_{t}^{i m+} \\
& +P_{t}^{b m+}-P_{t}^{s p-}-P_{t}^{i m-}-P_{t}^{b m-} \quad \forall t
\end{aligned}
$$

Limits on trading volumes in the electricity markets These limits are imposed by the electricity markets operation and their characteristics. Total power sold in the markets should not be greater than system capacity (35). Furthermore, liquidity of intraday and balancing markets is limited. Therefore, constraints (36-39) are used to avoid trading big quantities of power in these markets, which would not be applicable.

$$
\begin{aligned}
& P_{t}^{s p+}+P_{t}^{i m+}+P_{t}^{b m+} \leq \sum_{g=1}^{N_{G}} p_{g}^{\max } \cdot U_{g, t} \quad \forall t \\
& P_{t}^{i m+} \leq v o l_{t}^{I M} \quad \forall t \\
& P_{t}^{i m-} \leq \operatorname{vol}_{t}^{I M} \quad \forall t \\
& P_{t}^{b m+} \leq \operatorname{vol}_{t}^{B M \uparrow} \quad \forall t \\
& P_{t}^{b m-} \leq v o l_{t}^{B M \downarrow} \quad \forall t
\end{aligned}
$$

\section{Stochastic parameter modelling}

Stochastic parameters in this study consist of electricity prices in day-ahead, intraday, and balancing market and electricity volume traded in intraday and balancing markets. Figure 3 shows the values of the electricity prices in the three markets taken from Nord Pool [11] for three consecutive days. As it can be seen, prices present autocorrelation and interdependence. This is a general characteristic of electricity prices, and the reason why autoregressive models are used for modelling them.

\section{Day-ahead market}

Day-ahead electricity prices are modelled with a seasonal autoregressive integrated moving average (SARIMA) model as in [5]. Historical data from the Elspot day-ahead electricity market are used [11]. SARIMA models are suitable for fitting non-stationary data with some degree of seasonality. The general form of SARIMA model is: 


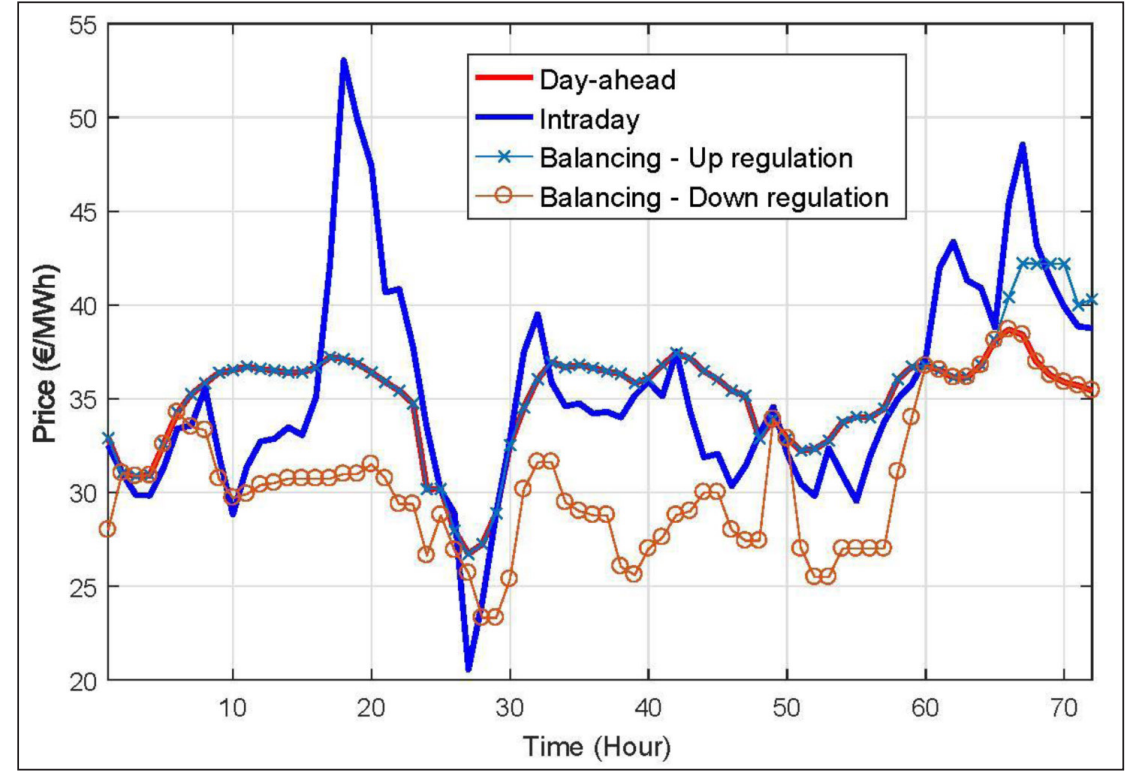

Fig. 3. Electricity prices in day ahead, intraday, and balancing markets for three consecutive days

$$
\varphi_{p}(B) \Phi(B)(1-B)^{D}\left(1-B^{s}\right) y_{t}=\theta_{q}(B) \Theta(B) \varepsilon_{t},(40)
$$

where $y_{t}$ is the time series value at period $t$, $\varphi_{p}(B)$ and $\theta_{q}(B)$ are the autoregressive and moving average functions of the back-shift operator $B: B^{l} y_{t}=y_{t-1}$ respectively, $\Phi(B)$ and $\Theta(B)$ are the seasonal autoregressive and moving average functions, respectively, $D$ is the non-seasonal integration degree, $s$ is the order of seasonality, and $\varepsilon_{t}$ is a white noise process (error or innovation distribution). Box-Jenkins methodology is used for building a qualitative forecasting model [12].

The model that is chosen for the day-ahead electricity prices is:

$$
\begin{aligned}
& \left(1-\varphi_{1} B_{1}-\varphi_{2} B_{2}\right)\left(1-\Phi_{24} B_{24}-\Phi_{48} B_{48}\right)(1-B) y_{t} \\
& =\left(1+\theta_{1} B_{1}+\theta_{2} B_{2}\right)\left(1+\Theta_{24} B_{24}+\Theta_{48} B_{48}\right) \varepsilon_{t},
\end{aligned}
$$

where $y_{t}$ is the day-ahead electricity price at period $t$. This model captures the daily pattern of electricity prices having two seasonal autoregressive and moving average parameters with 24 and 48 hours seasonality. Parameter values of the model are given in Table 1.

\section{Intraday market}

An autoregressive moving average with exogenous input (ARMAX) model is used to model intraday electricity prices following a similar approach as in [14]. Furthermore, an autoregressive (AR) model is used for the traded volumes. The exogenous input parameter in the ARMAX model is the day-ahead electricity prices. It should be noted that the intraday market in Nord Pool is a continuous market. The proposed model is a discrete approximation as it provides one price and one volume for each hour of the day. The model that is chosen for the intraday electricity prices is:

$$
\begin{aligned}
& \left(1-\varphi_{1} B_{1}-\varphi_{2} B_{2}-\varphi_{3} B_{3}-\varphi_{24} B_{24}\right) y_{t} \\
& =\beta x_{t}+\left(1+\theta_{24} B_{24}\right) \varepsilon_{t},
\end{aligned}
$$

where $y_{t}$ is the intraday electricity price and $x_{t}$ is the day-ahead electricity price at time $t . \beta$ is the regression component coefficient. The intraday volumes model is:

$$
\left(1-\varphi_{1} B_{1}-\varphi_{24} B_{24}-\varphi_{25} B_{25}\right) y_{t}=c+\varepsilon_{t}
$$

Table 1. Parameter values of day-ahead market prices model (SARIMA)

\begin{tabular}{c|c|c|c|c|c|c|c|c|c}
\hline & Parameter & $\boldsymbol{\varphi}_{\mathbf{1}}$ & $\boldsymbol{\varphi}_{\mathbf{2}}$ & $\boldsymbol{\Phi}_{\mathbf{2 4}}$ & $\boldsymbol{\Phi}_{\mathbf{4 8}}$ & $\boldsymbol{\theta}_{\mathbf{1}}$ & $\boldsymbol{\theta}_{\mathbf{2}}$ & $\boldsymbol{\Theta}_{\mathbf{2 4}}$ & $\boldsymbol{\Theta}_{\mathbf{4 8}}$ \\
\hline $\begin{array}{c}\text { Day-ahead } \\
\text { market }\end{array}$ & Price & 0.95 & -0.21 & 0.89 & 0.08 & -0.81 & -0.10 & -0.61 & -0.24 \\
\hline
\end{tabular}


where $y_{t}$ is the intraday volume in this case and $c$ a constant. Parameter values of the two models are given in Table 2 .

\section{Balancing market}

A method presented in [13] is used to model the balancing market prices and volumes. This method uses a combination of an AR model and a Markov state switching model. The AR model is used to model the values of market premiums (premium is the difference between the price in the balancing market and the price in the day-ahead market for the same period) while the Markov model is used to model the state transition of the prices. There are four states: (1) no balancing prices are defined at time $t,(2)$ only up regulation price is defined at time $t,(3)$ only down regulation price is defined at time $t$, and (4) both up and down regulation prices are defined at time $t$. Furthermore, the up regulation price is always greater than the day-ahead price for the same hour and the opposite is for the down regulation price. A similar approach is used for the volumes. The corresponding AR models for balancing market up regulation premiums and volumes are:

$$
\begin{aligned}
& \left(1-\varphi_{1} B_{1}-\varphi_{2} B_{2}-\varphi_{3} B_{3}\right) y_{t}=\varepsilon_{t}(44) \\
& \left(1-\varphi_{1} B_{1}-\varphi_{2} B_{2}-\varphi_{3} B_{3}-\varphi_{4} B_{4}\right) y_{t}=\varepsilon_{t}
\end{aligned}
$$

while for down regulation premiums and volumes are:

$$
\left(1-\varphi_{1} B_{1}\right) y_{t}=\varepsilon_{t}
$$

$$
\left(1-\varphi_{1} B_{1}-\varphi_{2} B_{2}\right) y_{t}=\varepsilon_{t}
$$

Parameter values of the four models are given in Table 3.

\section{Sample creation procedure}

The procedure to create a sample set of prices and volumes has 5 steps:

1. SARIMA model (41) is used to create 24 hourly prices in the day-ahead market for the following day.

2. Using day-ahead prices from the previous step and the ARMAX model (42), 24 hourly prices in the intraday market are created.

3. Using the AR model (43), 24 power volumes which are traded in the intraday market are created.

4. With the help of the Markov state model, 24 balancing market states are simulated for the next day.

5. The AR models (44-47) in combination with the balancing market states of the previous step are used to generate 24 premiums and volumes for up regulation and 24 premiums and volumes for down regulation in the balancing market. The premiums are then added to the day-ahead prices from step 1 to create the up and down regulation prices.

\section{CASE STUDY}

A case study is performed to test the performance of the proposed method. A DH system is considered which consists of 32 units. The type of each

\begin{tabular}{|c|c|c|c|c|c|c|c|c|c|}
\hline & Parameter & $\varphi_{1}$ & $\varphi_{2}$ & $\varphi_{3}$ & $\varphi_{24}$ & $\varphi_{25}$ & $\theta_{24}$ & $\beta$ & $c$ \\
\hline \multirow{2}{*}{ Intraday market } & Price & 0.66 & 0.04 & -0.06 & 0.01 & - & 0.13 & 0.37 & - \\
\hline & Volume & 0.78 & - & - & 0.17 & -0.11 & - & - & 83.3 \\
\hline
\end{tabular}
unit and their parameters are given in Table 4. BP stands for back-pressure, EC for extraction

\begin{tabular}{|c|c|c|c|c|c|c|}
\hline & & Parameter & $\varphi_{1}$ & $\varphi_{2}$ & $\varphi_{3}$ & $\varphi_{4}$ \\
\hline \multirow{4}{*}{$\begin{array}{c}\text { Balancing } \\
\text { market }\end{array}$} & \multirow{2}{*}{ Up regulation } & Premium & 0.88 & -0.33 & 0.17 & - \\
\hline & & Volume & 0.77 & -0.09 & 0.01 & 0.07 \\
\hline & \multirow{2}{*}{ Down regulation } & Premium & 0.81 & - & - & - \\
\hline & & Volume & 0.79 & -0.03 & - & - \\
\hline
\end{tabular}

Table 2. Parameter values of intra-day market prices (ARMAX) and intraday volumes (AR) models

Table 3. Parameter values of balancing market models 
Table 4. Case study system parameters

\begin{tabular}{|c|c|c|c|c|c|c|c|c|c|}
\hline \#Unit & 1 & 2 & 3 & 4 & 5 & 6 & 7 & 8-12 & $13-32$ \\
\hline Type & BP & BP & EC & GT & $\mathrm{HB}$ & $\mathrm{HB}$ & $\mathrm{HB}$ & EB & $\mathrm{HP}$ \\
\hline Fuel & Wood & Coal & Oil & Oil & Oil & Diesel & Oil & & \\
\hline$\lambda_{g}^{\text {fuel }}$ & 11 & 25 & 30 & 30 & 30 & 27 & 30 & & \\
\hline$C_{g}^{\text {start }}$ & $10^{4}$ & $10^{4}$ & $2 \times 10^{4}$ & $10^{3}$ & & & & & \\
\hline$\beta_{g}^{e l}$ & & & 3.5 & & & & & & \\
\hline$\beta_{g}^{\text {th }}$ & & & 0.3 & & & & & & \\
\hline$a_{g}$ & 0.6 & 0.6 & 0.6 & & & & & & \\
\hline$\eta_{g}$ & 0.9 & 0.88 & 0.87 & 0.85 & 0.88 & 0.87 & 0.87 & 0.98 & \\
\hline $\mathrm{cop}_{\mathrm{g}}$ & & & & & & & & & 3 \\
\hline$p_{g}^{\max }$ & 140 & 150 & 250 & 55 & & & & & \\
\hline$p_{g}^{\min }$ & 40 & 80 & 60 & 0 & & & & & \\
\hline$q_{g}^{\max }$ & 340 & 250 & 350 & 0 & 125 & 150 & 330 & 40 & 15 \\
\hline$q_{g}^{\min }$ & 100 & 160 & 0 & 0 & 35 & 30 & 35 & 0 & 0 \\
\hline
\end{tabular}

condensing, GT for gas turbine, HB for heat boiler, EB for electric boiler, and HP for heat pump. When there is no value, it means that the specific parameter is not applicable to that type of unit. Two different system configurations are considered, one without any heat storage and one with $500 \mathrm{MWh}_{\text {th }}$ heat storage capacity.

For each one of the two configurations a Monte Carlo simulation is conducted considering a maximum number of 3000 sample sets. That means the model is solved 6000 times in total for both configurations. Results are shown in Table 5 for the first configuration and Table 6 for the second. Results are presented for various sizes of the sample set, starting from 1 sample set and going up to 3000. Mean simulation time and the minimum, maximum, average and standard deviation values of the objective function are provided.

In a Monte Carlo simulation the optimal solution is considered to have been reached when the average value and standard deviation have been stabilized. If this does not happen, then the simulation continues with more samples. In this case, as it can be seen in Fig. 4, for the first system configuration,

Table 5. Simulation results (system without heat storage)

\begin{tabular}{|c|c|c|c|c|c|c|c|c|}
\hline & ples & 1 & 20 & 100 & 600 & 1000 & 2000 & 3000 \\
\hline \multicolumn{2}{|c|}{ Mean time [sec] } & 4.20 & 1.58 & 1.48 & 0.25 & 0.74 & 0.74 & 0.49 \\
\hline \multirow{4}{*}{ 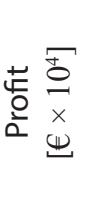 } & Min. & 5.79 & 4.02 & 3.40 & 2.23 & 2.23 & 2.23 & 2.23 \\
\hline & Mean & 5.79 & 6.81 & 6.77 & 6.69 & 6.70 & 6.69 & 6.67 \\
\hline & Max. & 5.79 & 10.61 & 10.61 & 11.72 & 13.00 & 14.82 & 14.82 \\
\hline & Std. & 0 & 1.45 & 1.59 & 1.60 & 1.59 & 1.56 & 1.57 \\
\hline
\end{tabular}

Table 6. Simulation results (system with heat storage)

\begin{tabular}{|c|c|c|c|c|c|c|c|c|}
\hline & oles & 1 & 20 & 100 & 600 & 1000 & 2000 & 3000 \\
\hline \multicolumn{2}{|c|}{ Mean time [sec] } & 1.63 & 1.49 & 1.48 & 1.50 & 1.50 & 0.74 & 0.72 \\
\hline \multirow{4}{*}{ 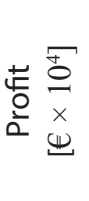 } & Min. & 6.29 & 4.63 & 3.92 & 2.54 & 2.54 & 2.54 & 2.54 \\
\hline & Mean & 6.29 & 7.62 & 7.57 & 7.50 & 7.52 & 7.51 & 7.51 \\
\hline & Max. & 6.29 & 11.84 & 11.84 & 13.40 & 14.73 & 16.19 & 16.19 \\
\hline & Std. & 0 & 1.63 & 1.78 & 1.80 & 1.79 & 1.75 & 1.76 \\
\hline
\end{tabular}




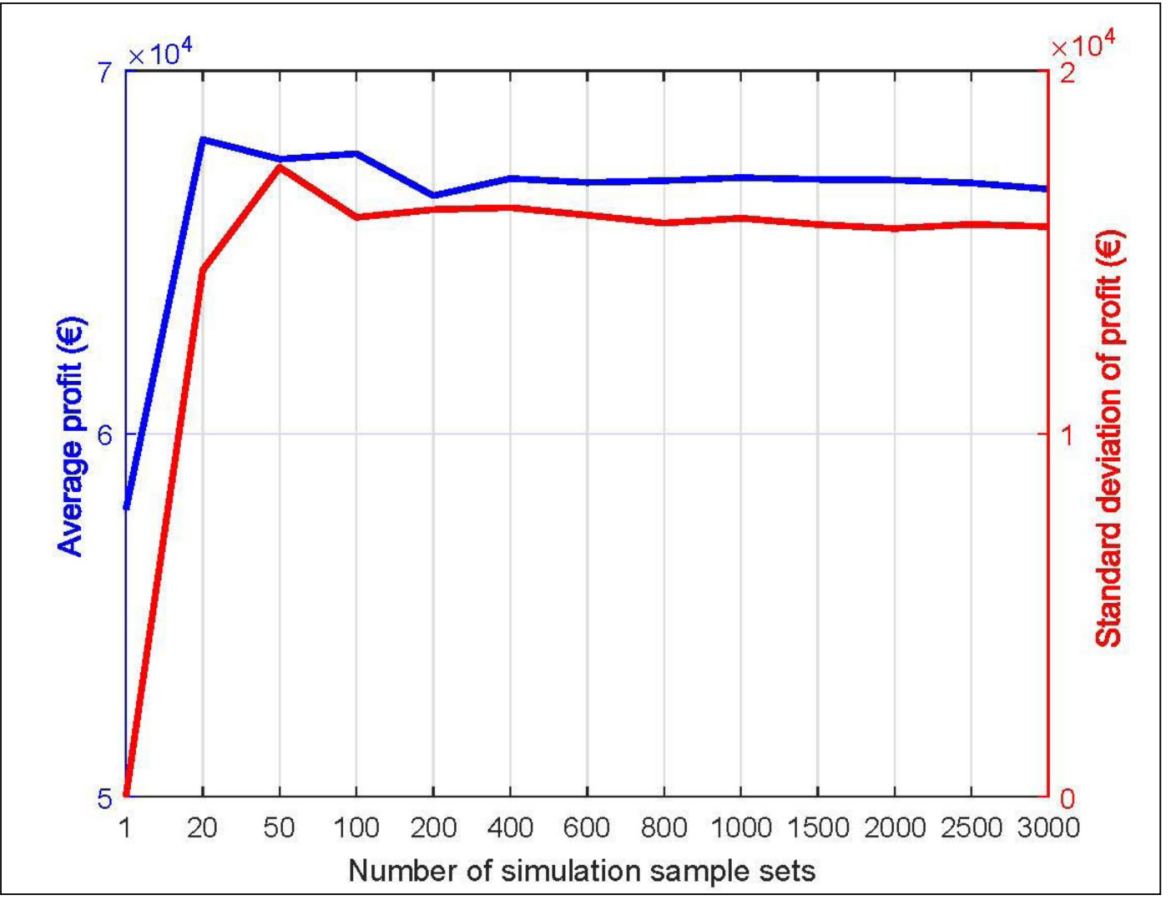

Fig. 4. Evolution of the mean value and standard deviation of profit with the number of sample sets

this happens after approximately 400 sample sets. Considering also the low mean simulation time, it can be said that the method is quite fast.

Comparing results in Tables 5 and 6, there is an increase of the mean profit by approximately $11 \%$, when a heat storage is used. The daily profit distribution for the first configuration system is shown in Fig. 5. It should be clarified that this profit includes only the income from electricity sold to the markets.

Finally, Fig. 6 shows the share of power and heat generation among the units of the system. The electricity price values and volatility are such that only unit 1 and unit 2 share almost the total generation. These units have the lower fuel cost as seen in Table 4.

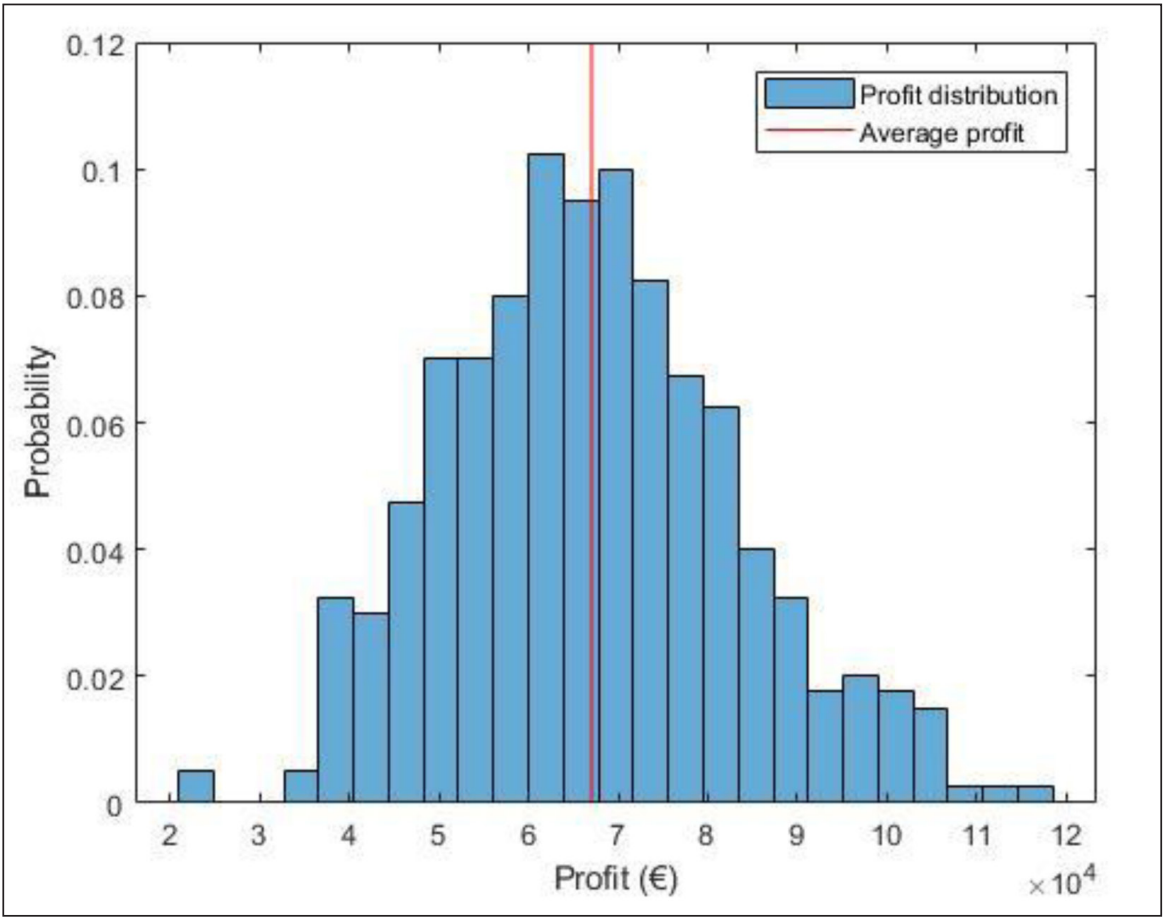

Fig. 5. Probability distribution function of the daily profit 


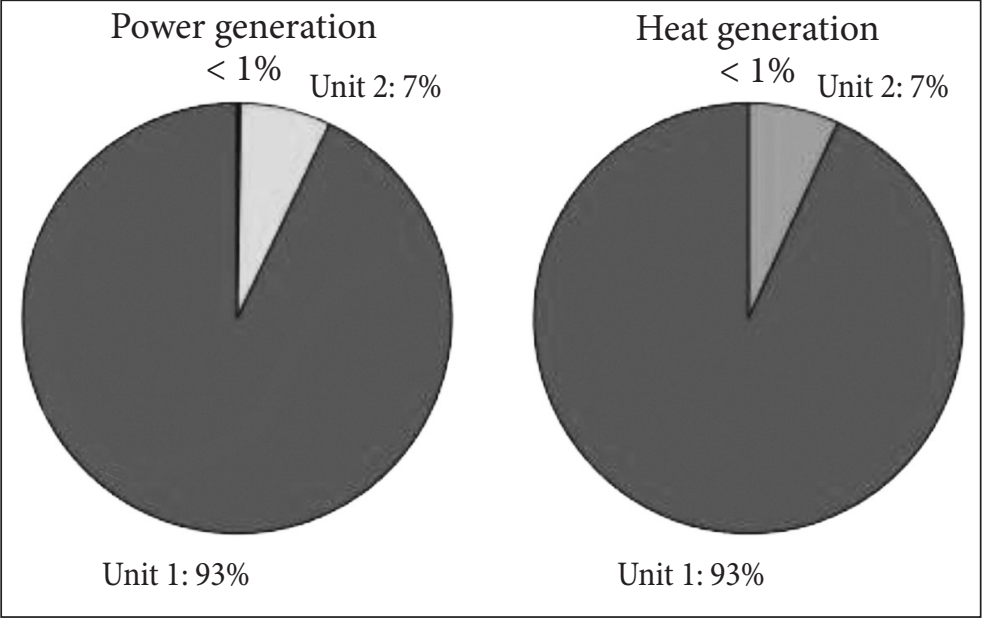

Fig. 6. Power and heat generation share

\section{CONCLUSIONS}

This paper provides the mathematical formulation of the DH system short-term operation scheduling problem. The model is used in a Monte Carlo simulation where the stochastic parameters of electricity prices and volumes are modelled with the help of autoregressive models. The case study shows that the method is quite fast. Furthermore, as it is expected, the use of heat storage increases the expected profit.

\section{ACKNOWLEDGEMENTS}

This work was sponsored by SweGRIDS, the Swedish Centre for Smart Grids and Energy Storage, www.swegrids.se.

Received 1 March 2017 Accepted 15 May 2017

\section{NOMENCLATURE}

\begin{tabular}{|c|c|c|c|}
\hline \multicolumn{4}{|c|}{ Indices and numbers } \\
\hline$g$ & Index of units, running from 1 to $N_{G}$ & $q^{\text {flow }}$ & Maximum flow to and from storage \\
\hline$t$ & $\begin{array}{l}\text { Index of time periods in hourly resolution, } \\
\text { running from } 1 \text { to } N_{T}\end{array}$ & $v o I_{t}^{B M \uparrow}$ & $\begin{array}{l}\text { Volume traded in balancing market for } \\
\text { up regulation }\end{array}$ \\
\hline \multicolumn{2}{|c|}{ Parameters } & $v o I_{t}^{B M \downarrow}$ & $\begin{array}{l}\text { Volume traded in balancing market for } \\
\text { down regulation }\end{array}$ \\
\hline$\lambda_{t}^{\text {spot }}$ & Day-ahead market price & $v o l_{t}^{I M}$ & Volume traded in intraday market \\
\hline$\lambda_{t}^{i m}$ & Intraday market price & $q_{t}^{\text {load }}$ & Heat demand \\
\hline$\lambda_{t}^{b m-}$ & Balancing market down regulation price & $I_{g}$ & Minimum on time \\
\hline$\lambda_{t}^{b m+}$ & Balancing market up regulation price & $f_{g}$ & Minimum off time \\
\hline$\lambda_{g}^{\text {fuel }}$ & Fuel price & \multicolumn{2}{|c|}{ Variables } \\
\hline$C_{g}^{\text {start }}$ & Start-up cost & $\begin{array}{c}P_{t}^{s p+} \\
\end{array}$ & Power sold to day-ahead market \\
\hline$C_{g}^{\text {stop }}$ & Shut down cost & $P_{t}^{s p-}$ & Power bought from day-ahead market \\
\hline$c^{\text {shed }}$ & Heat shedding cost & $P_{t}^{i m+}$ & Power sold to intraday market \\
\hline$\beta_{g}^{e l}$ & Marginal fuel consumption for power production & $P_{t}^{i m-}$ & Power bought from intraday market \\
\hline$\beta_{g}^{\text {th }}$ & Marginal fuel consumption for heat production & $P_{t}^{b m+}$ & Power sold to balancing market \\
\hline
\end{tabular}




\begin{tabular}{llll}
\hline$p_{g}^{\max }$ & Power generation capacity & $P_{t}^{b m-}$ & Power bought from balancing market \\
\hline$p_{g}^{\min }$ & Power generation lower limit & $P_{t, t}^{f u e l}$ & Fuel consumption \\
\hline$q_{g}^{\max }$ & Heat generation capacity & $P_{g, t}$ & Power generation \\
\hline$q_{g}^{\min }$ & Heat generation lower limit & $P_{g, t}^{\text {con }}$ & Power consumption \\
\hline$a_{g}$ & Power-to-heat ratio & $Q_{g, t}$ & Heat generation \\
\hline$\eta_{g}$ & Efficiency & $Q_{g, t}^{m 1}$ & Heat generation in mode 1 \\
\hline$c o p$ & Coefficient of performance & $Q_{g, t}^{m 2}$ & Heat generation in mode 2 \\
\hline$f$ & Heat storage losses parameter & $Q_{t}^{\text {shed }}$ & Heat shedding \\
\hline$v^{\max }$ & Heat storage capacity & $V_{t}$ & Heat storage content \\
\hline$v^{\min }$ & Heat storage lower limit & $U_{g, t}$ & Unit commitment binary variable \\
\hline$r_{g}^{q \uparrow}$ & Upward ramp rate for heat & $Y_{g, t}$ & Start-up binary variable \\
\hline$r_{g}^{q \uparrow}$ & Downward ramp rate for heat & $Z_{g, t}$ & Shut-down binary variable \\
\hline$r_{g}^{p \uparrow}$ & Upward ramp rate for power & $M_{g, t}^{1}$ & Binary variable for mode 1 \\
\hline$r_{g}^{p \uparrow}$ & Downward ramp rate for power & $M_{g, t}^{2}$ & Binary variable for mode 2 \\
\hline & & &
\end{tabular}

\section{References}

1. Connolly D. et al. Heat Roadmap Europe 2050: First pre-study for the EU27, 2012.

2. Puttgen H. B., MacGregor P. R. Optimum scheduling procedure for cogenerating small power producing facilities. IEEE Transactions on Power Systems. 1989. Vol. 4. No. 3. P. 957-964.

3. Aringhieri R., Malucelli F. Optimal operations management and network planning of a district heating system with a combined heat and power plant. Annals of Operations Research. 2003. Vol. 120. No. 1-4. P. 173-199.

4. De Ridder F., Claessens B. A trading strategy for industrial CHPs on multiple power markets. International Transactions on Electrical Energy Systems. Feb. 2013.

5. Dimoulkas I., Amelin M. Probabilistic dayahead CHP operation scheduling. Power \& Energy Society General Meeting, 2015 IEEE. P. 1-5.

6. Zugno M., Morales J. M., Madsen H. Robust management of combined heat and power systems via linear decision rules. Energy Conference (ENERGYCON), 2014 IEEE International. P. 479-486.

7. Kroese D. P., Taimre T., Botev Z. I. Handbook of Monte Carlo Methods, 1st edition. Hoboken, N. J: Wiley, 2011.
8. Granelli G. P., Marannino P., Montagna M., Zanellini F. Monte Carlo based unit commitment procedures for the deregulated market environment. International Journal of Electrical Power \& Energy Systems. 2006. Vol. 28. No. 10. P. 712-722.

9. Valenzuela J., Mazumdar M. Monte Carlo computation of power generation production costs under operating constraints. IEEE Transactions on Power Systems. 2001. Vol. 16. No. 4. P. 671-677.

10. Hamon C., Perninge M., Söder L. An importance sampling technique for probabilistic security assessment in power systems with large amounts of wind power. Electric Power Systems Research. 2016. Vol. 131. P. 11-18.

11. Nord Pool Spot [Online]. Available: http://www. nordpoolspot.com

12. Box G. E. P., Jenkins G. M., Reinsel G. C. Time Series Analysis: Forecasting and Control. Hoboken, N.J.: John Wiley, 2008.

13. Olsson M., Soder L. Modeling real-time balancing power market prices using combined SARIMA and Markov processes. IEEE Transactions on Power Systems. 2008. Vol. 23. No. 2. P. 443-450.

14. Nogales F. J. Forecasting intra-day electricity prices by time-series models (submitted to IEEE Transactions on Power Systems). 
Ilias Dimoulkas, Mikael Amelin

CENTRALIZUOTO ŠILUMOS TIEKIMO SISTEMOS VEIKLOS TRUMPUOJU LAIKOTARPIU MODELIAVIMAS TAIKANT MONTE KARLO METODĄ

Centralizuoto šilumos tiekimo sistemose energija dažnai gaminama kogeneracinèse jègainèse, kurios efektyviai gali gaminti tiek šilumos, tiek elektros energiją. Be šių jègainių, tikslui pasiekti gali būti naudojami vandens šildymo katilai, elektriniai šildytuvai, šilumos siurbliai ir šilumos saugojimo talpos. Kogeneracija ir galimybė sukaupti šilumą, kuri bus panaudota vèliau sistemos valdymui, kelia nemažai iššūkių. Be to, didelèse centralizuoto šilumos tiekimo sistemose gaminama elektros energija yra parduodama elektros energijos rinkose. Todèl sistemos veiklos planavimo problema tampa dar sudètingesnè, nes reikia atsižvelgti i elektros energijos kainų neapibrèžtumą rinkose. Siekiant optimaliai spręsti neapibrèžtumus yra taikomi įvai- rūs matematinio optimizavimo įrankiai, pavyzdžiui, stochastinis programavimas ir optimizavimas. Šiame straipsnyje aprašomi rezultatai, gauti taikant tradicini Monte Karlo modeliavimo metodą. Iš pradžių matematiškai formuluojamas centralizuoto šilumos tiekimo sistemos veiklos trumpuoju laikotarpiu ir elektros prekybos modelis. Tada šis modelis naudojamas parinktai sistemai modeliuoti Monte Karlo metodu, o modelio stochastinių parametrų reikšmès apskaičiuojamos taikant autoregresinius modelius. Rezultatai parodè, kad skaičiavimai yra greiti ir reikalauja tik 300-400 skaičiavimų konvergavimui. Dviejų sistemos konfigūracijų palyginimas parodè, kad šilumos saugojimas kasdien padidina tikètiną pelną $11 \%$. Galiausiai, elektros energijos kainos nepastovumas šiuo atveju yra toks, kad didžiąją dalị laiko daugiausia veikia du kogeneracinès jègainès blokai.

Raktažodžiai: centralizuotas šilumos tiekimas, kogeneracija, trumpalaike veikla, modeliavimas Monte Karlo metodu, elektros rinkos 